Pak. j. sci. ind. res. Ser. B: bio. sci. 2021 64B(3) 256-262

\title{
Comparative Study of Mineral Content in Different Varieties of Green Tea
}

\author{
Anila Bashir ${ }^{\mathrm{a}}$, Muhammad Sajid ${ }^{\mathrm{a}}$, Farrukh Siyar Hamid ${ }^{\mathrm{b}}$, Abdul Waheed ${ }^{\mathrm{b} *}$, Madiha Bashir $^{\mathrm{b}}$, \\ Hussain Shah ${ }^{\mathrm{c}}$, Nadia Khan ${ }^{\mathrm{b}}$, Seemab Ali ${ }^{\mathrm{b}}$ and Naveed Ahmed \\ ${ }^{a}$ Department of Biochemistry, Hazara University, Mansehra, KPK, Pakistan \\ ${ }^{b}$ National Tea and High Value Crops Research Institute, Shinkiari, Mansehra, Pakistan \\ 'Plant Sciences Division, PARC, Islamabad, Pakistan
}

(received March 18, 2019; revised December 11, 2019; accepted January 20, 2020)

\begin{abstract}
Camellia sinensis L. leaves composed of different concentrations of mineral contents play a vital role in human nutrition and health. In this study, locally processed three different green tea varieties i.e. P3, P5 and P9 were used for mineral content determination at National Tea and High Value Crops Research Institute (NTHRI), Shinkiari, Mansehra, Pakistan. Atomic absorption spectrophotometer, flame photometer and Kjehldal apparatus were used for the determination of mineral concentration in all the collected tea samples. Mineral composition of tea samples were identified in the following quantity order: high level of nitrogen (37300 to $41380 \mathrm{mg} / \mathrm{L})$, calcium $(515.6$ to $522.1 \mathrm{mg} / \mathrm{L})$ and phosphorus $(742$ to 1220 $\mathrm{mg} / \mathrm{L}$ ) were observed in all tea samples compared to other minerals. Cobalt (Co), molybdenum (Mo), sodium $(\mathrm{Na})$, zinc $(\mathrm{Zn})$, nickel $(\mathrm{Ni})$ and copper $(\mathrm{Cu})$ were highest in $\mathrm{P} 3$, while least amount was identified in $\mathrm{P} 5$, variety. On the contrary, calcium $(\mathrm{Ca})$, potassium $(\mathrm{K})$ and lead $(\mathrm{Pb})$ contents were maximum in $\mathrm{P}$, while minimum were in P3. This study revealed that the levels of mineral elements in different varieties of green tea vary from the permissible level but the monitoring of their levels in tea plant is obligatory for future risk measurements.
\end{abstract}

Keywords: Camellia sinensis L., varieties, samples, minerals, atomic absorption spectrophotometer

\section{Introduction}

Tea is the infused leaves extract of $C$. sinensis L. and one of the most consumable drinks worldwide after water (Xiao et al., 2008). Statistical figures showed that average tea consumption throughout the world is 4 fluid ounces per day per capita (Zhu et al., 2006). However, per capita consumption of tea in Pakistan is more than one kilogram after the United Kingdom and all of its tea is being imported from the other tea producing countries, proved Pakistan the second largest tea importing country in the world (Latif et al., 2008).

Tea minerals are the most important ingredients due to their nutritional and physiological roles. All types of minerals such as sodium $\left(\mathrm{Na}^{+}\right)$, calcium $\left(\mathrm{Ca}^{+}\right)$, potassium $\left(\mathrm{K}^{+}\right)$, manganese $\left(\mathrm{Mn}^{+}\right)$, magnesium $\left(\mathrm{Mg}^{+}\right)$, zinc $\left(\mathrm{Zn}^{+}\right)$, phosphorus $\left(\mathrm{P}^{+}\right)$and Iron $\left(\mathrm{Fe}^{+}\right)$are present in Tea (Han and $\mathrm{Li}, 2002$ ). Macro minerals of tea are $\mathrm{Mg}, \mathrm{Ca}, \mathrm{Na}$, $\mathrm{K}, \mathrm{P}, \mathrm{S}, \mathrm{Mn}$ and $\mathrm{Al}$ which generally can be found in $\mathrm{mg} / \mathrm{g}$ level (Herrador et al., 2001). On the other hand, micro-minerals of tea are $\mathrm{Fe}, \mathrm{Cu}, \mathrm{Zn}, \mathrm{B}, \mathrm{Sr}, \mathrm{Co}, \mathrm{Ni}, \mathrm{Rb}$, $\mathrm{Cr}, \mathrm{Ba}$ and Ti and generally can be found both in $\mu \mathrm{g} / \mathrm{g}$ and mg/g level (Fernandez et al., 2002). Most abundant

*Author for correspondence; E-mail: abdulw900@gmail.com of these micro-minerals in tea are $\mathrm{Zn}, \mathrm{Fe}$ and $\mathrm{Cu}$ (Seenivasan et al., 2008; Shen et al., 2008). Research has shown that besides essentially required secondary metabolites and minerals, some toxic elements such as $\mathrm{As}, \mathrm{Cd}, \mathrm{Hg}$ and $\mathrm{Pb}$ may also be present in tea leaves (Han et al., 2006).

To sustain proper function of human body mineral intake is essential in daily diet. Micro mineral like manganese is required as an essential nutrient for several enzymes to function properly and play a key role for normal bone development, brain function and nervous system (Liang et al., 2006). Copper is associated with impaired health in deficiencies as well as in excess. Copper deficiency results bone disorders and anemia (Uauy et al., 1998). Zinc is a key element in the majority of the human metabolic pathways. Deficiency of zinc may be responsible for growth retardation, loss of appetite, skin changes and immunological defects (Reddy et al., 2007).

When teas are brewed, different chemical compositions including minerals are extracted differentially into infusions, making the infused beverage a vital source of macro and micro mineral constituents (Chen et al., 2009). Some nutritionally important minerals are 
essentially required in daily intake on the basis of RDA and tea may be the best source of these important minerals but if minerals levels exceeds from its RDA they may also be toxic to human body, especially in case of accumulation (Han et al., 2006). Habitual use of such tea may have adverse effect on human health. Therefore, a detailed study on mineral content of the local tea varieties could be helpful to understand the levels of minerals in these teas and to recommend for daily intake. Unfortunately, no such research on locally grown tea varieties has been conducted before. Hence, the present study was designed with three locally grown tea varieties in Fig. 1 i.e. P3, P5 and P9 to understand the mineral contents and their nutritional and physiological importance in daily human nutrition.

\section{Materials and Methods}

All the research work pertaining to field, processing and laboratory for investigations was carried out at National Tea and High Value Crops Research Institute (NTHRI), Shinkiari, Mansehra and COMSATS University of Information and Technology Abbottabad, Pakistan.

Morphological features of selected tea varieties for the study. P3. P3 belongs to Camellia sinensis and best for green tea. It has minimum inter-nodal distance and numerous plucking points with good canopy. Leaves are narrow, early flusher and the variety is cold and drought tolerant.

P5. P5 belongs to Camellia sinensis and best for both black and green tea. Plants possess large shiny leaves with inter-nodal space having 3-6 cm. Physical appearance is very attractive. Good plant frame/canopy and high yielder. Late flusher but sufficient plucking points.

P9. P9 belongs to Camellia sinensis and best for both black and green tea. Leaf less shiny than P5 and leaf size intermediate between P3 and P5. It is low yielder compared to P5.

Sample collection and preparation. Fresh leaves of all the 03 varieties were collected and processed for green tea at NTHRI processing factory. Samples were collected randomly for further procedure.

Determination of nitrogen by Kjeldahl apparatus. Nitrogen content was determined by kjeldahl apparatus (VELP UDK 159). First step of nitrogen determination was digestion of samples. $0.25 \mathrm{~g}$ of each tea was treated

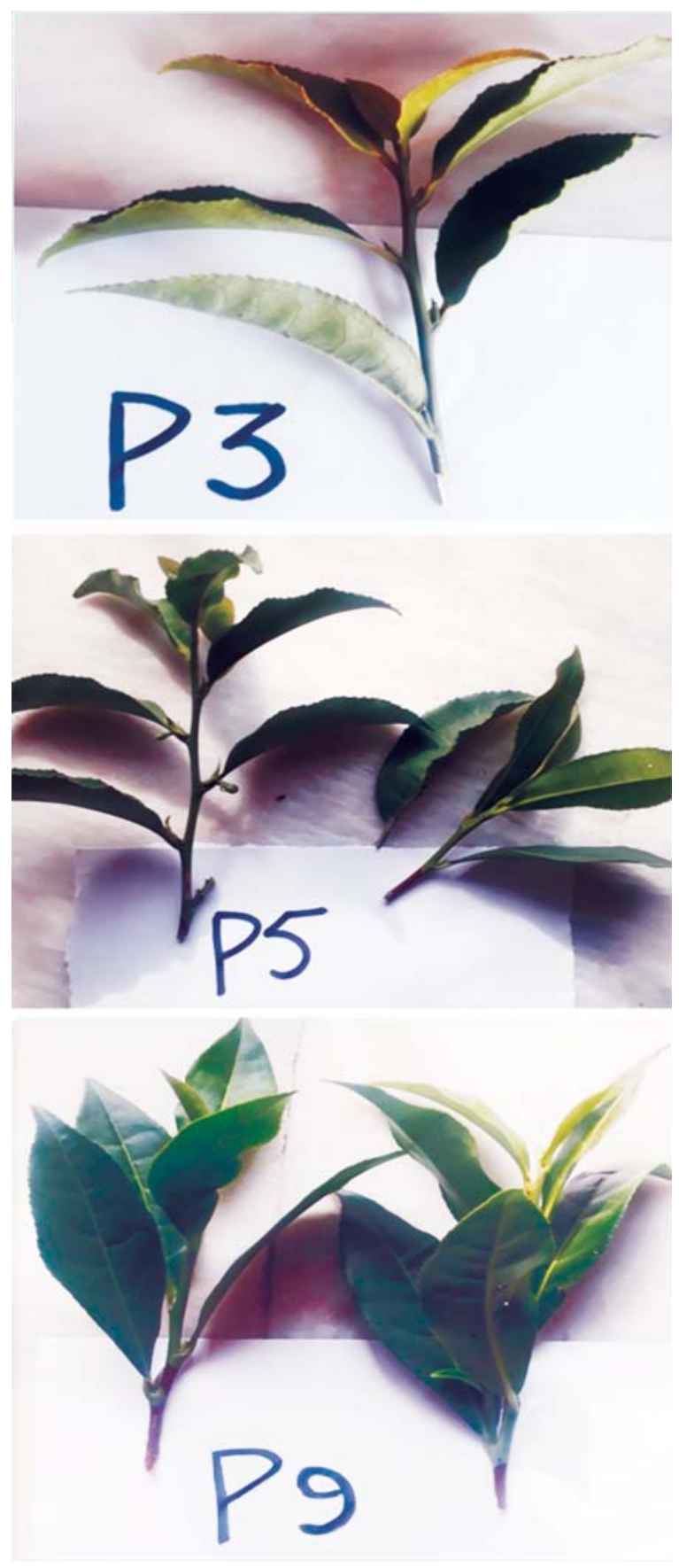

Fig. 1. Tea varieties $\mathrm{P} 3, \mathrm{P} 5$ and $\mathrm{P} 9$.

with conc. $\mathrm{H}_{2} \mathrm{SO}_{4}$ for $3 \mathrm{~h}$ until transparent solution was obtained. Followed by distillation, all material was diluted with $250 \mathrm{~mL}$ of distilled water and then treated with $10 \mathrm{~mL}$ of $40 \% \mathrm{NaOH}$ in distillation apparatus. Finally titration took place, $2 \%$ boric acid obtained in a flask and methyl red added as an indicator, thus ammonia was released. Collected solution was titrated 
against 0.1 normal $\mathrm{H}_{2} \mathrm{SO}_{4}$. Gentle reading was noted manually on Kjeldahl apparatus (AACC (2000)'s method 46-13).

Sample preparation for mineral analysis. Samples of different varieties of green tea. Processed green tea leaves of all the 03 varieties (P3, P5 and P9) obtained from NTHRI Shinkiari, Mansehra for making powder were placed in desiccators to prevent gaining moisture.

Digestion of samples for mineral analysis. Dried powdered samples of all the 03 varieties of green tea were digested. One gram of each tea sample obtained in a $100 \mathrm{~mL}$ of digestion flask and treated with $20 \mathrm{~mL}$ mixture of $\mathrm{HCL}, \mathrm{H}_{2} \mathrm{SO}_{4}$, and $\mathrm{HNO}_{3}$ in 10:4:1 ration by volume. Initially heated gently and then vigorously.

a. Standard potassium dihydrogen phosphate $\left(\mathrm{KH}_{2} \mathrm{PO}_{4}\right)$ solution. A quantity of $2.19 \mathrm{~g} \mathrm{KH}_{2} \mathrm{PO}_{4}$ dried at $105^{\circ} \mathrm{C}$ and $1000 \mathrm{~mL}$ volumetric flask filled with distilled water $+2.19 \mathrm{~g}+\mathrm{KH}_{2} \mathrm{PO}_{4}$ to prepare 500 ppm stock solution.

Sodium and potassium determination by flame photometry. Flame photometer works on the principle that excited atoms of certain element emits a characteristic wave-length, when return to their ground state. This type of emitted radiation is related to kind and amount of the element.

Reagents. Ammonium acetate. Glacial acetic acid $1 \mathrm{~N}$ : $60 \mathrm{~mL}$ and $75 \mathrm{~mL}$ of ammonium hydroxide (app. 25\% $\mathrm{NH}_{3}$ ) were diluted to one liter. The $\mathrm{pH}$ adjusted to 7.0 by addition of either ammonium hydroxide or acetic acid.

Potassium standard 1000 ppm. Dried $\mathrm{KCl} 1.9069 \mathrm{~g}$ by weigh was dissolved and diluted to $01 \mathrm{~L}$ with ammonium acetate.

Sodium standard 1000 ppm. Dried $\mathrm{NaCl} 2.5419 \mathrm{~g}$ by weigh was dissolved and diluted to $01 \mathrm{~L}$ with ammonium acetate.

Mineral analysis by atomic absorption spectroscopy. Selected minerals were analyzed by digested sample solution. The mineral elements were magnesium $(\mathrm{Mg})$, iron $(\mathrm{Fe})$, zinc $(\mathrm{Zn})$, manganese $(\mathrm{Mn})$, calcium $(\mathrm{Ca})$, cobalt $(\mathrm{Co})$, copper $(\mathrm{Cu})$, lead $(\mathrm{Pb})$, nickel $(\mathrm{Ni})$, aluminum (Al) and molybdenum (Mo) were analyzed by atomic absorption spectrophotometer (AAS).

Spectrophotometer determination was based on reaction with a suitable reagent, certain element develop specific colour and intensity. Organic phosphorus treated with ammonium molybdate $\left(\left(\mathrm{NH}_{4}\right)_{6} \mathrm{Mo}_{7} \mathrm{O}_{24} 4 \mathrm{H}_{2} \mathrm{O}\right)$ formed ammonium phosphor-molybdate, which were reduced to made molybdenum blue. Absorbance of sample for the concentration of phosphate was measured at 470 $\mathrm{nm}$ of wave length.

Reagents. Batrons reagent (Mixture $A+B$ ). Solution A. Ammonium molybdate $25 \mathrm{~g}$ added into $400 \mathrm{~mL}$ of distilled water and mixed before filtered.

Solution B. $300 \mathrm{~mL}$ of water was boiled and $1.5 \mathrm{~g}$ of ammonium vanadate added in it and left for cooling, $25 \mathrm{~mL}$ of conc. $\mathrm{HNO}_{3}$ was added and cooled again.

Solution $(\mathrm{A}+\mathrm{B})$. Solution A poured into B to make volume of $01 \mathrm{~L}$ with distill water.

Sulphuric acid. (1:6, acid + water ratio)

Statistical Analysis. The mean and Least Significant Difference (LSD) values were analyzed statistically by using STATISTIX software at 5\% level of significance (Steel and Torrie, 1980).

\section{Results and Discussion}

Minerals are primary metabolites, play a vital role in growth and development of organisms and responsible for many physiological functions like nervous, skeletal system and also cellular reactions. Millions of the people throughout the world take tea as a beverage so analysis of mineral nutrients becomes critical (Olivier et al., 2011). In this study, different macro and micro minerals were identified in leaves of the selected tea varieties which are summarized below.

Macro mineral. The results of macro mineral composition of all the 03 different tea varieties (green tea samples) are presented below in Figs. 2-5. Tea basically grown for its vegetative produce has higher concentration of $\mathrm{N}$ as compared to other elements. Fig. 2 represented that the $\mathrm{N}$ content in different tea varieties (for green tea samples) ranged from 37300 to 41380 $\mathrm{mg} / \mathrm{L}$. According to ADI, nitrate ion value is $3.7 \mathrm{mg} / \mathrm{Kg}$ of body mass. Among all of the selected tea varieties; P3 had significantly the higher quantity of $\mathrm{N}$ content followed by P5 and lowest was in P9.

The level of P ranged from 742 to $1220 \mathrm{mg} / \mathrm{L}$ (Fig. 3), whereas RDA recommendation for phosphorus is 3500 $\mathrm{mg} / \mathrm{L}$. Results revealed that a higher level of phosphorus was in P3 variety samples as compared to other two varieties while the lowest was observed in $\mathrm{P} 9$ variety. This might be due to varietal features and leaf character. Phosphorus is a vital mineral in the human body after 
calcium and possesses various functions such as bone mineralization, energy metabolism and framework of DNA and RNA structure (Golub, 2011).

The amount of Ca ranges between 515.6 to $522.1 \mathrm{mg} / \mathrm{L}$ in the samples in this study (Fig. 3), whereas comparative values of RDA for calcium is $400 \mathrm{mg} / \mathrm{L}$. From the result it was observed that $\mathrm{Ca}$ content was a bit higher in the variety P5 as compared to P9 and P3 but all are comparable to each other. Fresh tea leaves being used for the processing of green tea may be the main reason of higher values of calcium content. However, this value is obtained from the dry green tea samples and in the tea infusion it should be less. Calcium plays a critical role in strengthening of bones, muscle formation and better heart functioning; therefore increased levels of calcium contents would be necessary for human body which can be obtained from tea (Obiajunwa et al., 2002).

Potassium is a fundamental constituent for plant development; it is the cofactor which has functions in protein synthesis and activation of enzymes. In the current study, K concentration varied from 47.97 to $50.00 \mathrm{mg} / \mathrm{L}$ (Fig. 4) while RDA value for potassium is $5400 \mathrm{mg} / \mathrm{L}$. Similar to the previous results of $\mathrm{Ca}$, the mean values concerning potassium content $(\mathrm{K})$ in $\mathrm{P5}$ showed slightly higher concentration compared to the other two varieties but they were comparable to each other.

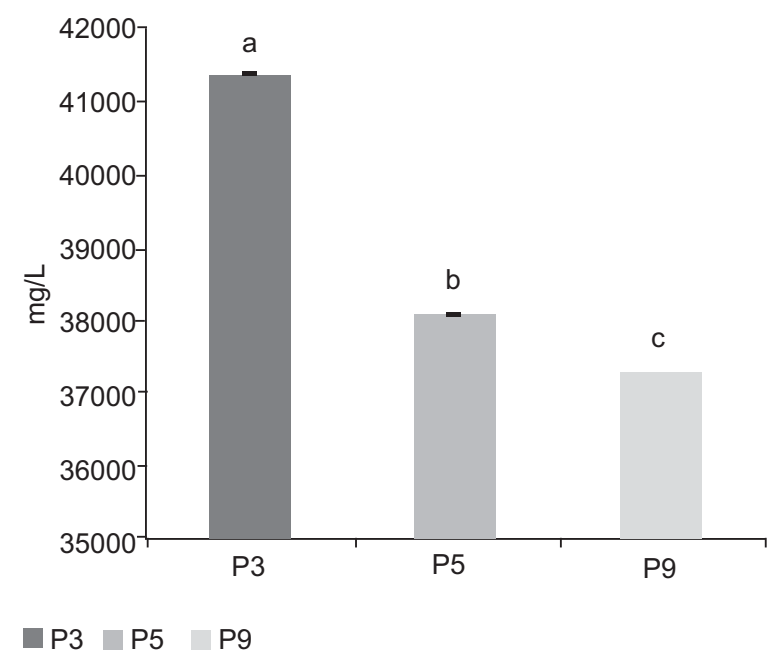

Fig. 2. Nitrogen concentration in green tea samples of different tea varieties. Data show the mean \pm SD. Means denoted by different letter are significantly different $(\mathrm{P}<0.05)$.
The Na concentration is ranged between 18.00 to 23.68 $\mathrm{mg} / \mathrm{L}$ in the samples in this study (Fig. 4) and the RDA value is $268000 \mathrm{mg} / \mathrm{L}$. Maximum sodium content was observed in P3 variety green tea samples followed by P5 and P9. However, P3 was comparable with P5 and P5 was comparable with P9. Sodium has vital role in enzymatic processes as cell activator, it is mainly associated with cell membrane function and also necessary for muscle functioning (Constantin and Alexandru, 2011).

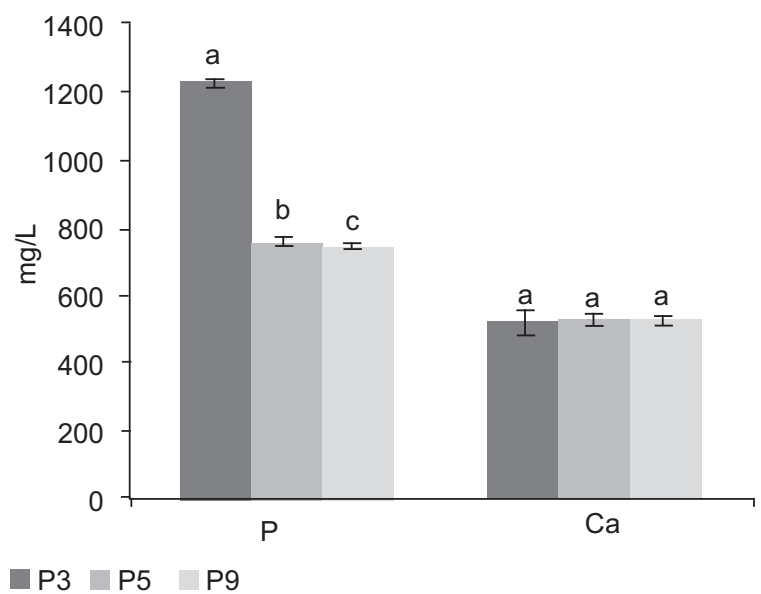

Fig. 3. Level of phosphorus and calcium in green tea samples of different varieties. Data show the mean \pm SD. Means denoted by different letter are significantly different $(\mathrm{P}<0.05)$.

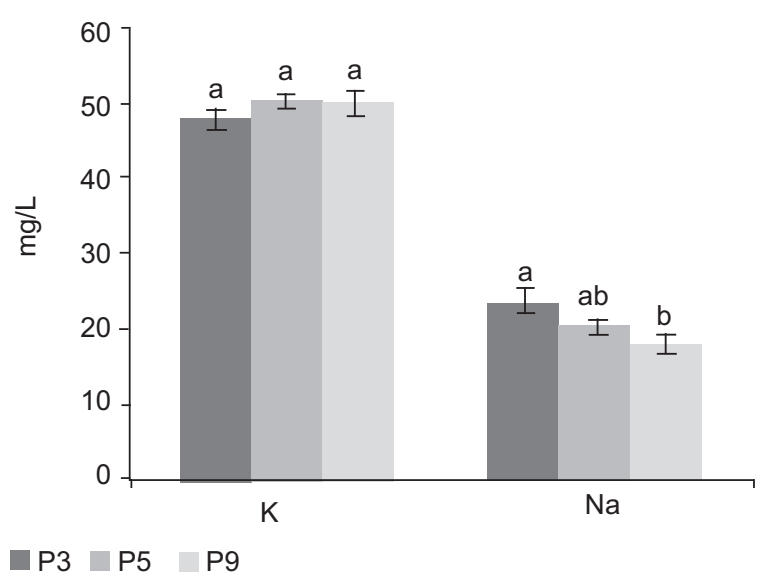

Fig. 4. Concentration of potassium and sodium in green tea samples of different varieties. Data show the mean \pm SD. Means followed by different letter are significantly different $(\mathrm{P}<0.05)$. 
The concentration of $\mathrm{Mg}$ among all tea varieties varied from 1.425 to $2.080 \mathrm{mg} / \mathrm{L}$ (Fig. 5). In P9 tea sample the higher amount of $\mathrm{Mg}(2.080 \mathrm{mg} / \mathrm{L})$ was observed that was followed by P3 and P5. Magnesium is an indispensable mineral element having role in maintenance of bones and teeth structure and also acts as more than 300 enzymes activator in human body (Romani, 2014).

Micro minerals. The results of micro mineral composition of all the 03 different tea varieties (green tea samples) are presented below in Figs. 6-7. Among the micro minerals aluminum was most abundant in the green tea samples which ranged between 51.65 to 67.50 mg/L (Fig. 6). Data clearly showed that P9 contained significantly higher amount of aluminum $(67.50 \mathrm{mg} / \mathrm{L})$ among the three varieties followed by P5 and P3. This result is more or less similar to the findings of Tadayon et al., (2011). A high amount of Al content in the majority of the tea samples investigated is not unexpected because tea plant was acknowledged as high aluminum accumulator due to being acidic in nature. As aluminum is abundantly available in acidic soil, it is the most vital mineral nutrition of tea plant.

WHO set limit for $\mathrm{Pb}$ is $10 \mu \mathrm{g} / \mathrm{g}$, while the findings of the present study showed that the $\mathrm{Pb}$ content of the green tea samples ranged between 0.309 to $23.64 \mathrm{mg} / \mathrm{L}$ (Fig. 6). P5 tea samples were found with highest $\mathrm{Pb}$ concentration $(23.64 \mathrm{mg} / \mathrm{L})$ and this concentration is at a risky level. In the $\mathrm{P} 3$ variety the $\mathrm{Pb}$ concentration is

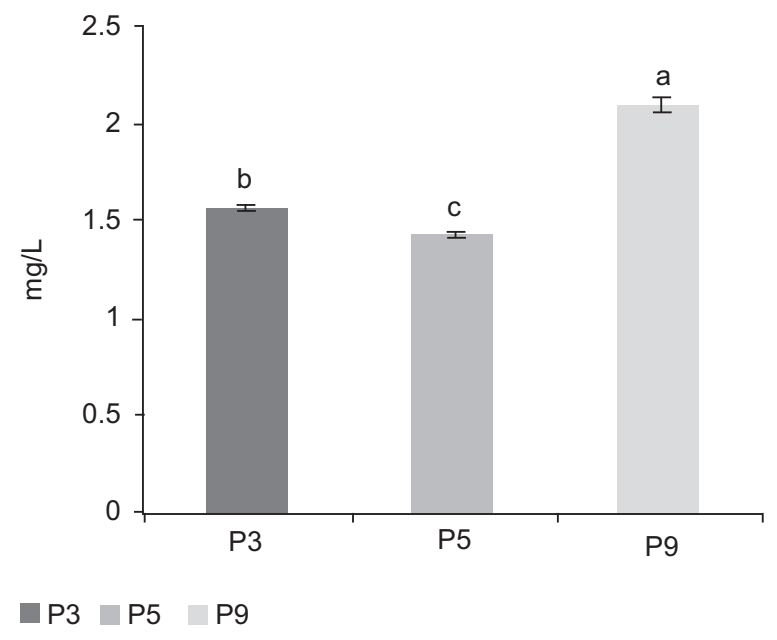

Fig. 5. Magnesium concentration in green tea samples of different varieties. Data show the mean \pm SD. Means denoted by different letter are significantly different $(\mathrm{P}<0.05)$. quite low than the P5, and lowest was identified in the P9 variety. These results are somewhat similar with the results of Milani et al. (2015). Jin et al. (2005) reported that soil media could be the main source of provision of $\mathrm{Pb}$ in tea. Growth of tea plants takes place mostly in high acidic soil where level of $\mathrm{Pb}$ is higher, hence soil and water pollution can lead to high $\mathrm{Pb}$ concentration in tea leaves (Han et al., 2006).

Iron is considered a necessary micronutrient in all type of plants particularly in tea plant. According to the findings of this study the $\mathrm{Fe}$ contents of all green tea samples were in between 0.570 to $1.031 \mathrm{mg} / \mathrm{L}$ (Fig. 7) as comparable with the results of Tadayon et al. (2011). Maximum level of Fe was observed in P9 $(1.031 \mathrm{mg} / \mathrm{L})$ tea sample that was followed by P3 and P5. The RDA value for iron is $2600 \mathrm{mg} / \mathrm{L}$. Iron is a key element for all living organisms. It plays a momentous role in different metabolic process such as electron and oxygen transportation.

Manganese is necessary for proper functioning of several enzymes as it acts as activator for more than 35 different enzymes (Liang et al., 2006). In this study, the concentration of $\mathrm{Mn}$ in green tea samples of different varieties was in between 0.0012 to $0.211 \mathrm{mg} / \mathrm{L}$ (Fig. 7). Significantly the highest was in the P9 and that was followed by P5 and P3. Present findings are quite concord with the results reported by Tadayon et al. (2011).

Likewise other minerals zinc is also a portentous mineral element here and in this study it ranged from 0.655 to

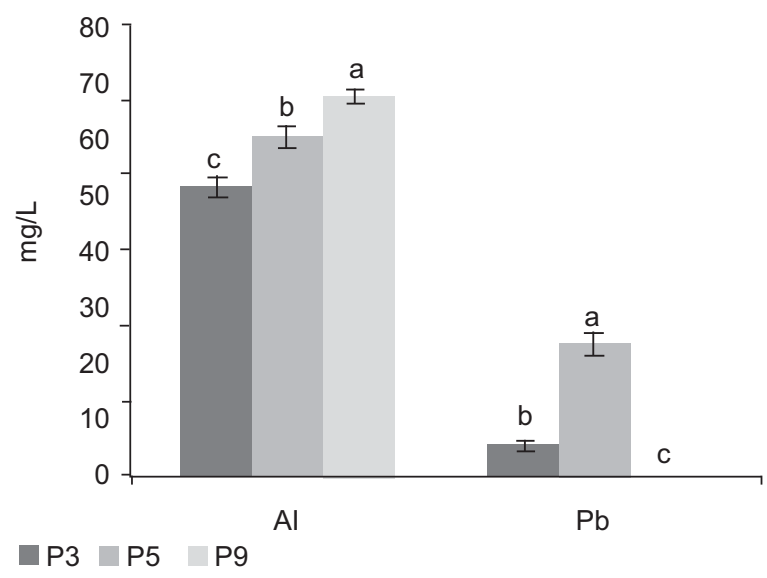

Fig. 6. Aluminum and phosphorus concentration in green tea samples of different varieties. Data show the mean $\pm \mathrm{SD}$. Means denoted by different letter are significantly different $(\mathrm{P}<0.05)$. 
$1.316 \mathrm{mg} / \mathrm{L}$ (Fig. 7). It was found that P3 sample has highest amount of zinc content $(1.316 \mathrm{mg} / \mathrm{L})$ than that of other green tea varieties and the concentrations in P5 and P9 are comparable to each other. Metabolic activity of 300 enzymes depends upon the zinc in human body as reported by Deshpande et al. (2013) that it is very crucial for protein, DNA synthesis and cell division.

Copper is one of the indigenous metals found in tea followed by $\mathrm{Zn}$ and $\mathrm{Al}$ (Seenivasan et al., 2008). Copper content varied greatly in the investigated green tea samples and the contents were ranged from 0.040 to $0.448 \mathrm{mg} / \mathrm{L}$ (Fig. 7). Maximum level of copper content $(0.448 \mathrm{mg} / \mathrm{L})$ was observed in P3 sample followed by P9 and P5. Copper is an obligatory mineral element having critical function in connective tissue, bone maintenance, proper growth and development in human body.

Molybdenum contents of green tea samples in this study varied between 0.947 to $1.102 \mathrm{mg} / \mathrm{L}$ (Fig. 7). Variety P3 showed significantly the highest Mo content (1.102 $\mathrm{mg} / \mathrm{L}$ ) compared to the other green tea varieties. The discrepancy in mineral contents of various type of tea leaves may be due to numerous factors such as different plant species, fertilizer application, soil property, climatic condition and generic differences.

Among the micro nutrients, Ni was also identified in this study but at a very low level and only in the green tea samples of the P3 tea variety at a concentration of $0.004 \mathrm{mg} / \mathrm{L}$. No other tea variety possessed Ni. It was suggested that fertilizers are the major cause of nickel

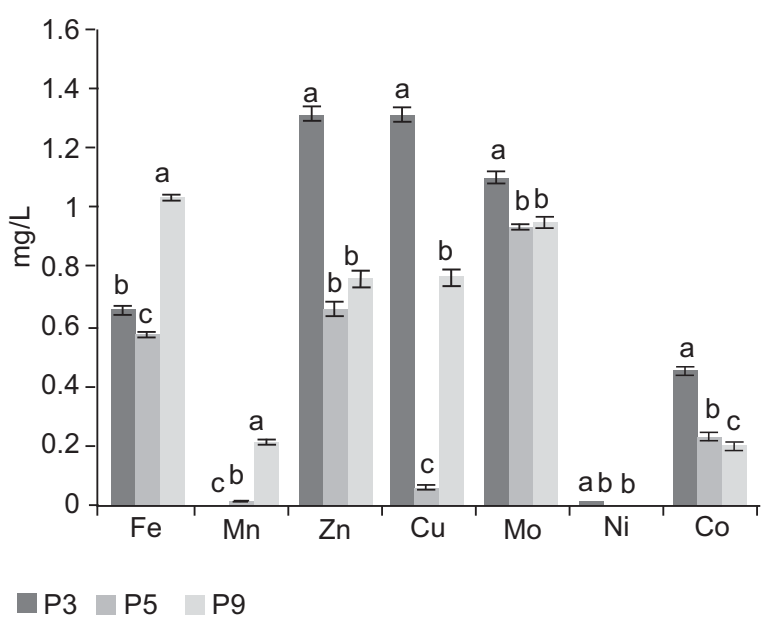

Fig. 7. Micro mineral concentration in green tea samples of different varieties. Data show the mean \pm SD. Means denoted by different letter are significantly different $(\mathrm{P}<0.05)$. contamination (Marcos et al., 1998). Since $\mathrm{Ni}$ is a contaminated element, therefore its acceptable limit in tea is not recommended.

Results indicated that the concentrations of cobalt (Co) in all green tea samples varied from 0.201 to 0.451 in $\mathrm{mg} / \mathrm{L}$ (Fig. 7). The WHO acceptable values for Co concentration is $0.015 \mathrm{mg} / \mathrm{Kg}$. P3 sample showed maximum level of Co content $(0.451 \mathrm{mg} / \mathrm{L})$, which was followed by P5 and P9 samples. Tea have been found to be sensitive to many inorganic ions including $\mathrm{Na}, \mathrm{Pb}$ and $\mathrm{Co}$ when applied to plants in excessive quantities a resulting their concentration being increased in the final product (Ranganthan et al., 1981).

\section{Conclusion}

All the selected tea varieties under study differed to each other considering the mineral contents. Particularly resulted for high content of ash of nitrogen which is quite clear evidence that tea have a richest source of mineral elements. Highest amount of nitrogen $(\mathrm{N})$, phosphorus $(\mathrm{P})$, sodium $(\mathrm{Na})$, zinc $(\mathrm{Zn})$, copper $(\mathrm{Cu})$, molybdenum (Mo), nickel $(\mathrm{Ni})$ and cobalt $(\mathrm{Co})$ were identified in the green tea samples of $\mathrm{P} 3$ variety whereas the least amount recorded in P5 variety. It was also observed that P5 showed maximum level of calcium $(\mathrm{Ca})$, potassium $(\mathrm{K})$ and lead $(\mathrm{Pb})$ contents while low level of these mineral elements were present in P3 variety. On the other hand, the concentration of magnesium $(\mathrm{Mg})$, aluminum $(\mathrm{Al})$, iron $(\mathrm{Fe})$ and manganese (Mn) observed higher in P9 samples. Green tea has demonstrated to be a rich source of $\mathrm{Na}, \mathrm{P}, \mathrm{N}$, $\mathrm{K}, \mathrm{Ca}, \mathrm{Al}$ and $\mathrm{Mg}$. The observed level of mineral elements in different varieties of green tea are below the permitted level but regular monitoring of their levels in tea is obligatory for future risk measurements. The study provides a better knowledge regarding the quality of selected tea varieties of NTHRI, Shinkiari. Similarly, it provides a solid foundation for consumer's preference. $\mathrm{P} 5$ tea variety was found with higher $\mathrm{Pb}$ concentration i.e. $23.64 \mathrm{mg} / \mathrm{L}$ which is above the threshold level of human body. Further study can be carried out to investigate the main cause of lead contamination in P5 variety and precautionary measurements should be carried out to avoid its hazardous effects.

\section{References}

AACC. 2000. The American Association of Cereal Chemists. Approved methods of analysis 10th Ed. St Paul MN.

Chen, Y.X., Yu, M.G., Xu, J., Chen, X.C., Shi, J.Y. 
2009. Differentiation of eight tea (Camellia sinensis) cultivars in China by elemental fingerprint of their leaves. Journal of Science of Food and Agriculture, 89: 2350-2355.

Constantin, M., Alexandru, I. 2011. The role of sodium in the body. Balneo-Research Journal, 2: 70-74. DOI 10.12680/balneo.2011.1015

Deshpande, J.D., Joshi, M.M., Giri, P.A. 2013. Zinc: the trace element of major importance in human nutrition and health. International Journal of Medical Sciences and Public Health, 2: 1-6.

Fernandez, P.L., Pablos, F., Martin, M.J., Gonzalez, A.G. 2002. Multi element analysis of tea beverages by inductively coupled plasma atomic emission spectrometry. Food Chemistry, 76: 483-489.

Golub, E.E. 2011. Bio-mineralization and matrix vesicles in biology and pathology. Seminar in Immunopathology, 33: 1947-1956.

Han, L.X., Li, R. 2002. Determination of minerals and trace elements in various tea by ICP-AES. Spectroscopy and Spectral Analysis, 22: 304-306

Han, W.H., Liang, Y.R., Yang, Y.J., Ma, L. F., Ruan, J.Y. 2006. Effect of processing on the $\mathrm{Pb}$ and $\mathrm{Cu}$ pollution of tea in Chinese. Journal of Tea Science, 26: $95-101$.

Herrador, Z., Gadisa, E., Moreno, J., Nieto, J., Benito, A. 2001. Cross-sectional study of malnutrition and associated factors among school aged children in rural and urban settings of Fogera and Libo Kemkem districts, Ethiopia. PloS One, 9. doi: 10.1371/journal.pone. 0105880 .

Jin, C.W., Zheng, S.J., He, Y.F., Zhou, G.D., Zhou, Z.X. 2005. Lead contamination in tea garden soils and factors affecting its bioavailability. ChemosphereJournal, 59: 1151-1159.

Latif, A., Jan, A.U., Chishti, A.F., Fayaz, M., Hamid, F.S. 2008. Assessing potential of local tea production in Pakistan. Sarhad Journal of Agriculture, 24: 339-344.

Liang, P., Sang, H., Sun, Z. 2006. Cloud point extraction and graphite furnace atomic absorption spectrometry determination of manganese (II) and iron (III) in water samples. Journal of Colloid and Interface Science, 304: 486-490.

Marcos, A., Fisher, G., Ree, G., Hill, S.J. 1998. Preliminary study using trace element concentrations and a chemometrics approach to determine the geographical origin of tea. Journal of Analytical Atomic Spectroscopy, 113: 521-525.

Milani, N., McLaughlin, M., Hettiarachchi, G.M., Beak, D.G., Kirby, J.K., Stacey, S. 2012. Dissolution kinetics of macronutrient fertilizers coated with manufactured zinc oxide nanoparticles. Journal of Agriculture and Food Chemistry, 60: 3991-8. DOI: 10.1021/jf20519

Obiajunwa, E.I., Adebajo, A.C., Omobuwajo, O.R. 2002. Essential and trace element contents of some Nigerian medicinal plants. Journal for Radioanalytical Nuclear Chemistry, 252: 473-476.

Olivier, J., Symington, E.A., Jonker, N., Rampedi, I., Van Eeden, T.S. 2011. Comparison of the mineral composition of leaves and infusions of traditional and herbal teas. Sourth African Journal of Science, 108: $623,7$.

Ranganathan, V., Natesan, S., Bhat, S.S. 1981. Tolerance of mature tea to certain inorganic ions applied in foliar sprays. United Planters' Association of Southern India Tea Scientific Department Bulletin, 37: 8-25.

Reddy, K.J., Kumar, J.R., Ramachandraiah, C., Thriveni, T., Reddy, A. 2007. Spectrophotometric determination of zinc in foods using N-ethyl-3carbazolecarboxaldehyde- 3-thiosemicarbazone: evaluation of a new analytical reagent. Food Chemistry Research, 65: 75-86.

Romani, A. 2014. Magnesium in Health and Disease. Springer Science and Business Media Dordrecht, 13: 49-79.

Seenivasan, S., Manikanadan, N., Muraleedharan, N.N., Selvasundaram, R. 2008. Heavy metal content of black teas from south India. Food Control, 19: 746-749.

Steel, R.D.G., Torrie, J.H. 1980. Principles and Procedures of Statistics, Subsequent Edition, Mecgraw hill book co. Inc., New York, USA. http://researcherslinks.com/current-issues/Responseof-Cabbage-Cultivars.

Tadayon, F., Lahiji, N. 2011. Availability of essential and nonessential elements in tea samples produced in Iran. International Journal of Academic Research, 3: 1071.

Uauy, R., Olivares, M., Gonzalez, M. 1998. Essentiality of copper in humans. American Journal of Clinical Nutrition, 67: 952-959.

Xiao, J., Chen, X., Zhang, L., Talbot, S.G., Li, G.C., $\mathrm{Xu}, \mathrm{M}$. 2008. Investigation of the mechanism of enhanced effect of EGCG on Huperzine as inhibition of acetylcholinesterase activity in rats by a multi-spectroscopic method. Journal of Agriculture and Food Chemistry, 56: 910-915.

Zhu, Y., Huang, H., Tu, Y. 2006. A review of recent studies in China on the possible beneficial health effects of tea. International Journal of Food Science and Technology, 41: 333-340. 